\title{
Ultrasound Assisted Catheter-Directed Thrombolysis of Acute Pulmonary Embolism: A Review of Current Literature
}

\author{
Muhammad Asif Mangi ${ }^{1}$, Hiba Rehman ${ }^{2}$, Vikas Bansal ${ }^{3}$, Omer Zuberi ${ }^{4}$ \\ 1. Internal Medicine, Orange Park Medical Center, Orange Park, USA 2. Internal Medicine, Hamdard \\ University Hospital, Karachi, PAK 3. Critical Care Medicine, Mayo Clinic Jacksonville, Fl 4. Cardiology, \\ Orange Park Medical Center
}

$\square$ Corresponding author: Muhammad Asif Mangi,drmasif33@yahoo.com Disclosures can be found in Additional Information at the end of the article

\section{Abstract}

Pulmonary embolism continues as a very common and also presumably life-threatening disorder. For affected individuals with intermediate- as well as high-risk pulmonary embolism, catheter-based revascularization procedures have developed a possible substitute for systemic thrombolysis or for surgical embolectomy. Ultrasound-assisted catheter-directed thrombolysis is an innovative catheter-based approach; which is the main purpose of the present review article. Ultrasound-assisted catheter-directed thrombolysis is much more efficacious in reversing right ventricular dysfunction as well as dilatation in comparison to anticoagulation alone in individuals at intermediate risk. However, a direct comparison of ultrasound-assisted thrombolysis with systemic thrombolysis or surgical thrombectomy is not available.

Ultrasound-assisted thrombolysis with early intrapulmonary thrombolytic bolus could also be successful in high-risk patients, but unfortunately, data from randomized trials is limited. This review article recapitulates existing information on ultrasound-assisted thrombolysis for acute pulmonary embolism.

Received 06/28/2017

Review began 07/05/2017 Review ended 07/18/2017 Published 07/19/2017

(c) Copyright 2017

Mangi et al. This is an open access article distributed under the terms of the Creative Commons Attribution License CC-BY 3.0., which permits unrestricted use, distribution, and reproduction in any medium, provided the original author and source are credited.
Categories: Internal Medicine, Cardiology, Radiology

Keywords: ultrasound assisted thrombolysis, ekos, pulmonary embolism

\section{Introduction And Background}

Pulmonary embolism (PE) is one of the leading cause of mortality in the United States (US), accounting 5-10\% in-hospital mortality, 15\% 90 days mortality and 58\% mortality in the first hour in patients with hemodynamic compromise [1-3]. Pulmonary embolism results from occlusion of pulmonary trunk, main pulmonary artery, segmental or subsegmental branches by air, tumor, or blood clot. Symptoms and outcomes vary based on the severity and extent of occlusion. Pulmonary embolisms are categorized as small (low risk), sub-massive (intermediate risk) and massive (high risk). Small PEs does not cause right ventricular dysfunction and no hemodynamic compromise. Sub-massive PEs causes right ventricular dysfunction but no hemodynamic compromise. While massive PEs causes right ventricular dysfunction and hemodynamic compromise.

Massive and submassive PEs are associated with increased risk of morbidity and mortality and may require interventions to prevent the complication of PEs such as right heart failure and pulmonary artery hypertension (PAH) [4-7]. Systemic thrombolysis and surgical embolectomy carry a higher risk of complications. Systemic thrombolysis accounts for $20 \%$ risk of major hemorrhage and 3-5\% risk of hemorrhagic stroke [2,8], while surgical embolectomy accounts

How to cite this article

Mangi M, Rehman H, Bansal V, et al. (July 19, 2017) Ultrasound Assisted Catheter-Directed Thrombolysis of Acute Pulmonary Embolism: A Review of Current Literature. Cureus 9(7): e1492. DOI 10.7759/cureus. 1492 
27.2\% inpatient mortality rate [9]. Hence these interventions are limited to massive PE. However, for submassive PEs, ultrasound assisted catheter-directed thrombolysis (UACDT) has given us the promising results [10-11]. EkoSonic Endovascular System (EKOS Corporation, Bothell, Washington, United States) facilitates thrombolysis with the lower risk of bleeding and was tested in randomized clinical trials (RCTs) [12-13]. In one RCT, the UACDT was superior to heparin alone in reversing the right ventricular dysfunction at 24 hours without increased risk of bleeding in intermediate risk patients [12]. While in another trial UACDT improves the thrombus burden, right ventricular dilatation, and PAH with a lower risk of intracranial hemorrhage in both massive and submassive PEs [13]. It is because of these successful result, US Food and Drug Administration (FDA) approved the use of UACDT in patients with PE [14].

This review will elaborate current evidence and research on risk stratification of PE, UACDT safety, efficacy, limitation, and complications.

\section{Review}

\section{Risk stratification}

PE risk stratification is important as severity and outcome of PE depends on the risk and comorbidity. The patient can be asymptomatic or symptomatic with dyspnea, syncope or chest pain. Similarly, the treatment also varies on the severity of PE. For low-risk PE anticoagulation and early discharge is recommended and for intermediate to high-risk PE intensive care unit (ICU) admission and intervention is recommended. Risk and severity are determined on the basis of certain characteristics including right heart strain, clot burden, elevated cardiac enzymes or brain natriuretic peptide (BNP) or N-terminal pro b-type natriuretic peptide (NTpro-BNP) and hypotension [15-16].

High Risk/ Massive Pulmonary Embolism: Patients with massive PE usually present with syncope, dyspnea, hypoxemia, bradycardia, and hypotension. They have large clot burden, a residual clot in heart or clot in the proximal part of lower extremity veins like Iliofemoral veins. Due to clot burden, these patients often have hypotension and right heart strain, which makes higher cardiac enzymes, BNP, and proBNP. These types of patients are at high risk of decompensation and death and often required emergent interventions and ICU admission.

Intermediate Risk/ Submassive Pulmonary Embolism: Patients with sub-massive PE are hemodynamically stable, but they have right heart strain which makes higher cardiac enzymes, BNP and pro-BNP. They are at increased risk of decompensation and death [16]. They also required intervention and ICU admission to prevent decompensation and death.

Low Risk/ Small Pulmonary embolism: Patients with small PE are hemodynamically stable with no right ventricular strain. Patients with hypotension, right ventricular strain, history of coronary artery disease, residual deep vein thrombosis, PE in the central location, and hypoxia are the independent risk factors for clinical deterioration [17]. The absence of mentioned risk factor often labels the patient as a low risk which often requires anticoagulation and early hospital discharge [17].

\section{Ultrasound-assisted catheter-directed thrombolysis}

UACDT is a pharmaco-mechanical thrombolysis consists of a catheter system which deploys ultrasound waves into the blood clots [18]. Ultrasound facilitates the delivery of the thrombolytic agent into the blood clots [19-21]. Further Braaten, et al. described the mechanism of ultrasound assisted thrombolysis (UAT) on blood clot [20]. Ultrasound causes reversible disaggregation of uncrosslinked fibrin fibers, which create additional binding sites, hence promotes thrombolysis [20]. Moreover, ultrasound waves create low power acoustic 


\section{Cureus}

streaming, which also separates fibers to promote the penetration of the thrombolytic drug into the thrombus [19]. The EkoSonic Endovascular System (EKOS Corporation; Bothell, Washington, United States) is consists of three component, catheter which delivers the drug to the confined location, microsonic core wire which delivers high-frequency, low-energy intravascular ultrasound waves along the treatment area and control unit which control this whole process (Figure 1-2).

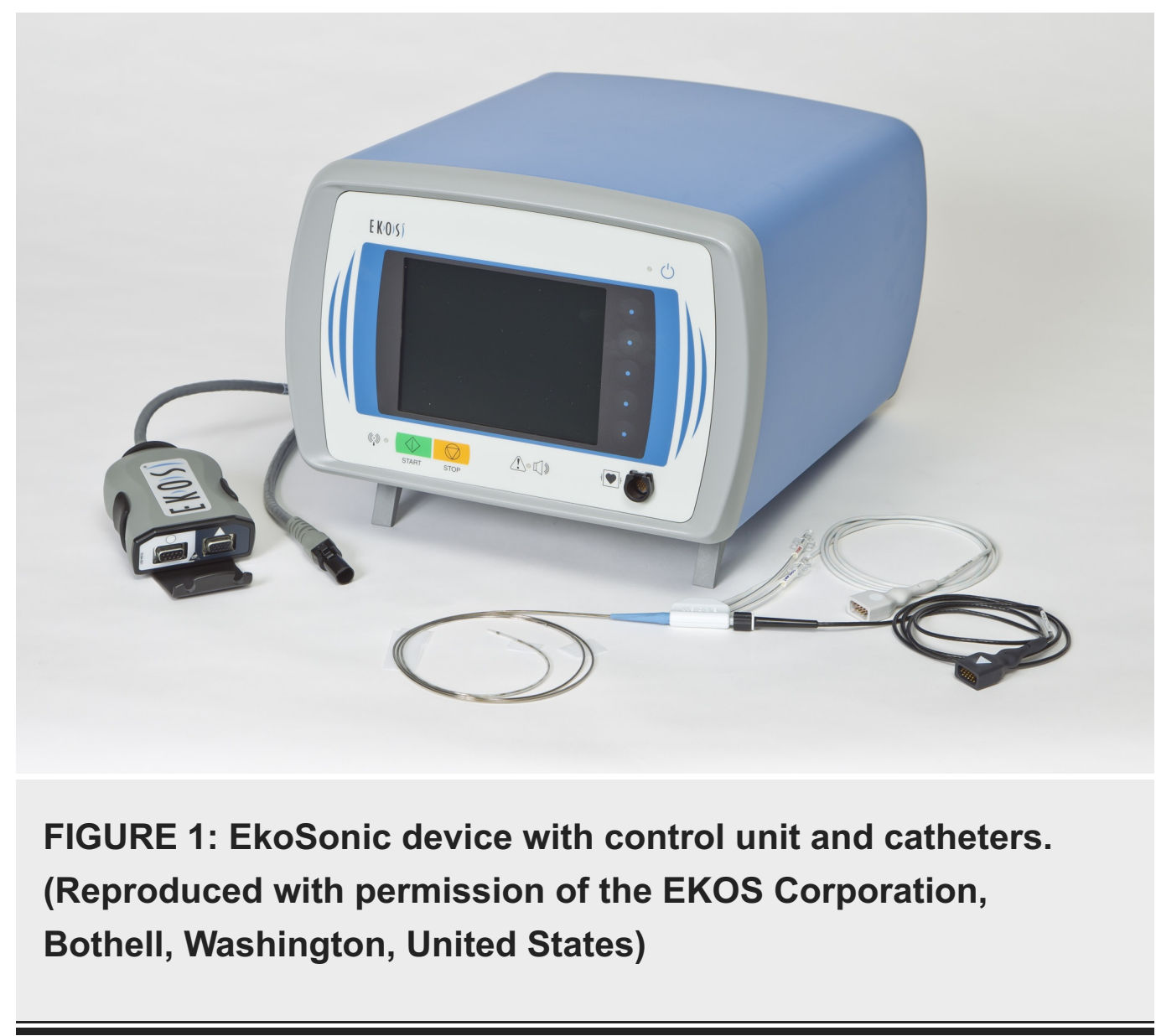




\section{Cureus}

\section{FIGURE 2: Closer view of the catheters (reproduced with permission of the EKOS Corporation, Bothell, Washington, United States)}

UACDT is an emerging field in the management of PE. Research is currently being conducted on the management of massive and submassive PE. In common, they used recombinant tissue plasminogen activator (rt-PA) as a thrombolytic agent. In some studies bolus of rt-PA was administered before UACDT [18,22]. Some studies used a fixed dose of rt-PA (10mg over 15 hours) per treated lung, while other used pulse infusion or slow infusion [12,18,23]. Treatment duration also varied among studies and outcome is guided by clinical or angiographic measures [11,24-26].

\section{Efficacy and safety of US-guided thrombolysis}

Efficacy of Ultrasound Assisted Catheter-Directed Thrombolysis: The most common parameter to guide treatment is right ventricular-to-left ventricular (RV/LV) ratio, which is a validated parameter to predict short-term mortality in patient with PE [6,27-28]. The studies have used this parameter to guide treatment of massive and submassive PE. In some studies, authors assessed RV/LV ratio before and after ultrasound-assisted thrombolysis (UAT) and they found a significant improvement of RV/LV ratio [12,18,22]. Engelhardt, et al. reported RV/LV ratio decreased from $1.33 \pm 0.24$ at baseline to $1.00 \pm 0.13$ at follow-up $(\mathrm{p}<0.001)$ and modified Miller score was significantly decreased from $17.8 \pm 5.3$ at baseline to $8.7 \pm 5.1$ at follow-up $(\mathrm{p}<0.001)$ [22]. The modified Miller score was used to assess pulmonary clot burden.

This gave us the promising result, as in randomized controlled Tenecteplase Italian Pulmonary Embolism (TIPES) trial, treatment group RV/LV ratio decrease from 1.36 to 1.03 [29]. In the treatment group, the patient received tenecteplase plus unfractionated heparin (UFH) were compared with the control group receiving UFH alone. The RV/LV ratio in the treatment group 
decreased from 1.36 to 1.04 over 24 hours compared to control group from 1.32 to 1.22 . Other variables which improved in patients receiving UAT were pulmonary artery pressure (PAP), clot burden, tricuspid annular plane systolic excursion and cardiac index [12,18,30-33]. Later on Kennedy, et al. described the effectiveness of UACDT in the retrospective study [11]. There was $\geqslant 90 \%$ thrombus clearance in $57 \%$ of the patients and $50 \%-90 \%$ thrombus clearance in $41 \%$ of the patients with PE over 19.6 hours \pm 6.0 . The PAP was decreased from $47 \mathrm{~mm} \mathrm{Hg} \pm 15$ at baseline to $38 \mathrm{~mm} \mathrm{Hg} \pm 12(\mathrm{P}<.001)$ and Miller score decreased from $25 \pm 3$ at baseline to $17 \pm 6(\mathrm{P}<.001)$. However, long-term benefit of early revascularization is still under debate. Some studies suggested that early revascularization decreases the risk of chronic pulmonary artery hypertension [34-36]. The consistent evidence in support of UACDT efficacy leading to the beginning of the randomized controlled trial (RCTs).

The Ultrasound Assisted Catheter-Directed Thrombolysis for Acute Intermediate risk Pulmonary Embolism (ULTIMA) trial was the first RCT of UACDT [12]. In this trial, they compared whether UACDT with anticoagulation is superior to anticoagulation alone in patients with intermediate risk PE. The investigator's hypothesis was based on TIPES trial, they hypothesized that UACDT has a similar effect in improving RV/LV ratio compared to tenecteplase [28]. Patients with acute symptomatic PE located at least at main or lower lobe pulmonary artery with RV/LV ratio $\geqslant 1$ were included. Total 59 patients were randomized (30 intervention group and 29 control group). The intervention group received rt-PA $10 \mathrm{mg}$ per treated lung with UFH and control group received UFH only. In intervention group mean RV/LV ratio decreased from $1.28 \pm 0.19$ at baseline to $0.99 \pm 0.17$ at 24 hours $(\mathrm{p}<0.001)$ while in control group mean RV/LV ratio decreased from $1.20 \pm 0.14$ to $1.17 \pm 0.20(\mathrm{p}=0.31)$. There was also a significant improvement in right ventricular systolic function in the intervention group. Subsequently Dumantepe, et al. evaluated the efficacy of UACDT in both massive and submassive PE and found $\geqslant 90 \%$ thrombus clearance in $77.2 \%$ of the patients, and $50 \%$ to $90 \%$ thrombus clearance in $22.8 \%$ of the patients [10]. They also discovered that PAP decreased from $67 \pm 14$ at baseline to $34 \pm 11 \mathrm{mmHg},(\mathrm{p}<0.001)$ at follow-up, RV/LV ratio decreased from $1.29 \pm$ 0.17 at baseline to $0.92 \pm 0.11$ at follow-up $(\mathrm{p}<0.001)$ and modified Miller score was significantly decreased from $28 \pm 4$ at baseline to $13 \pm 5$, $(\mathrm{p}<0.001)$ in $95 \%$ patients who survived to discharge. Further Engelberger, et al. retrospectively analyzed the safety and efficacy of UACDT [18]. He demonstrated mean pulmonary artery pressure (PAMP) decreased from $37 \pm 9 \mathrm{mmHg}$ at baseline to $25 \pm 8 \mathrm{mmHg}$ at $15 \mathrm{~h}(\mathrm{P}<0.001)$, cardiac index increased from $2.0 \pm 0.7$ at baseline to $2.7 \pm 0.9 \mathrm{~L} / \mathrm{min} / \mathrm{m}(\mathrm{P}<0.001)$, and $\mathrm{RV} / \mathrm{LV}$ ratio decreased from $1.42 \pm 0.21$ at baseline to $1.06 \pm 0.23$ at $24 \mathrm{~h}(\mathrm{P}<0.001)$. Most of the hemodynamic benefit was found in high-risk PE and in those with symptom duration < 14 days. Similarly Bagla, et al. conducted both retrospective and prospective study and found interesting finding relating to UACDT [37]. The main pulmonary artery pressure significantly decreased from $49.8 \mathrm{~mm} \mathrm{Hg}$ at baseline to $31.1 \mathrm{~mm} \mathrm{Hg}(\mathrm{P}<.0001)$ and RV/LV ratios decreased from 1.59 at baseline to $0.93(\mathrm{P}<.0001)$. These findings further lead to the beginning of another clinical trial. In Single-arm, Multicenter Trial of EkoSonic ${ }^{\circledR}$ Endovascular System and Activase for Treatment of Acute Pulmonary Embolism (SEATTLE II) trial, there were 150 patients (Acute massive 31, sub-massive 119) included in this study [13]. $24 \mathrm{mg}$ of rt-PA administered either as $1 \mathrm{mg} / \mathrm{h}$ for $24 \mathrm{~h}$ with a unilateral catheter or $1 \mathrm{mg} / \mathrm{h} /$ catheter for $12 \mathrm{~h}$ with bilateral catheters. Mean RV/LV diameter ratio decreased from baseline 1.55 to 1.13 at $48 \mathrm{~h}$ post-procedure $(\mathrm{p}<0.0001)$ and PAMP decrease from $51.4 \mathrm{~mm} \mathrm{Hg}$ to $36.9 \mathrm{~mm} \mathrm{Hg}(\mathrm{p}<0.0001$ ). They also observed decrease thrombus burden in patients treated with UACDT. It is because of these successful results, the use of UACDT was approved by the US FDA in May 2014 for the treatment of PE [14]. Further, in other retrospective studies, authors described other variables which significantly improved in UACDT, including pulmonary artery systolic, diastolic and mean pressure, main pulmonary artery diameter, tricuspid annular plane systolic excursion and Qanadli score [38,39]. Ozcinar, et al. in the prospective observational study also demonstrated the significance of UACDT in the patient with PE [40]. There were 38 patients enrolled in this study and 25 patients had bilateral UACDT with median rt-PA $21 \mathrm{mg}$ over median 15 hours. The median RV/LV ratio 


\section{Cureus}

decreased from 0.9(0.7-1.1) at baseline to $0.7(00.97),(\mathrm{p}=0.001)$ at six months follow-up and PAP decreased from $61.4 \pm 16.7$ to $37.2 \pm 9.1 \mathrm{mmHg}$ ( $\mathrm{p}=0.001)$. These findings collectively lead UACDT a better method of treating PE (Table 1). When compared to catheter-directed therapy alone, the UACDT provides similar efficacy but reduced time thrombolytic infusion time and treatment-related complications [19].

\begin{tabular}{|c|c|c|c|c|c|c|c|}
\hline Authors & $\begin{array}{l}\text { Study } \\
\text { Design }\end{array}$ & $\begin{array}{l}\text { Number of } \\
\text { patients }\end{array}$ & $\begin{array}{l}\text { Massive/Submassive } \\
\text { PE }\end{array}$ & Study details & Thrombolytic detail & $\begin{array}{l}\text { RV/LV } \\
\text { ratio } \\
\text { before } \\
\text { and after }\end{array}$ & $\begin{array}{l}\text { Other outcome } \\
\text { variables improved }\end{array}$ \\
\hline $\begin{array}{l}\text { Dumantepe, } \\
\text { et al. } 2014 \\
{[10]}\end{array}$ & Retrospective & $\begin{array}{l}\text { Total } 22 \text {, but } \\
19 \text { patients } \\
\text { have } \\
\text { symptoms } \\
<14 \text { days }\end{array}$ & $5 / 14$ & UACDT 22 & $\begin{array}{l}\text { Median dose of t-PA } 21.0 \mathrm{mg} \\
\text { (range } 16 \text { to } 35 \mathrm{mg} \text { ) }\end{array}$ & $\begin{array}{l}1.29 \pm \\
0.17 \text { vs } \\
0.92 \pm \\
0.11\end{array}$ & $\begin{array}{l}\text { Thrombus clearance } \\
\text { (complete, near } \\
\text { complete )PAP, } \\
\text { modified Miller score }\end{array}$ \\
\hline $\begin{array}{l}\text { Kennedy, et } \\
\text { al. } 2013[11]\end{array}$ & Retrospective & 60 & $12 / 48$ & UACDT 60 & Total t-PA dose $35.1 \mathrm{mg}$ & $\mathrm{N} / \mathrm{A}$ & $\begin{array}{l}\text { Thrombus clearance } \\
\text { (complete, near } \\
\text { complete, partial), } \\
\text { PAP, Miller score }\end{array}$ \\
\hline $\begin{array}{l}\text { Kucher, et } \\
\text { al. } 2013 \text { [12] }\end{array}$ & $\begin{array}{l}\text { Prospective } \\
\text { randomized } \\
\text { clinical trial }\end{array}$ & 59 & 0/59 & $\begin{array}{l}\text { UACDT 30, } \\
\text { UFH } 29\end{array}$ & Total t-PA 10-20mg & $\begin{array}{l}1.28 \pm 0.19 \\
\text { vs } \\
0.99 \pm 0.17\end{array}$ & $\begin{array}{l}\text { RV systolic function, } \\
\text { TAPSE, PAP, PAMP, } \\
\text { RA mean pressure, Cl }\end{array}$ \\
\hline $\begin{array}{l}\text { Piazza, et al. } \\
2014 \text { [13] }\end{array}$ & $\begin{array}{l}\text { Prospective } \\
\text { randomized } \\
\text { clinical trial }\end{array}$ & 150 & $31 / 119$ & UACDT 150 & Total t-PA dose $24 \mathrm{mg}$ & $\begin{array}{l}1.55 \mathrm{vs} . \\
1.13\end{array}$ & $\begin{array}{l}\text { PAMP, modified Miller } \\
\text { index score, GUSTO } \\
\text { score }\end{array}$ \\
\hline $\begin{array}{l}\text { Engelberger, } \\
\text { et al. } 2013 \\
\text { [18] }\end{array}$ & Retrospective & 52 & $14 / 32$ & UACDT 52 & $\begin{array}{l}\text { Total t-PA dose } 22.0+9.1 \mathrm{mg} \\
\text { for high-risk PE patients and } \\
20.1+3.7 \mathrm{mg} \text { for intermediate- } \\
\text { risk PE }\end{array}$ & $\begin{array}{l}1.42 \pm \\
0.21 \text { vs } \\
1.06 \pm \\
0.23\end{array}$ & Cl, PAMP \\
\hline $\begin{array}{l}\text { Engelhardt, } \\
\text { et al. } 2011 \\
\text { [22] }\end{array}$ & Retrospective & 24 & $5 / 19$ & UACDT 24 & $\begin{array}{l}\text { Mean t-PA dose } 33.5 \pm \\
15.5 \mathrm{mg}\end{array}$ & $\begin{array}{l}1.33 \pm \\
0.24 \text { vs } \\
1.00 \pm \\
0.13\end{array}$ & modified Miller score \\
\hline $\begin{array}{l}\text { Al-Hakim, et } \\
\text { al. } 2014 \text { [23] }\end{array}$ & Retrospective & 18 & $0 / 18$ & $\begin{array}{l}\text { UACDT 12, } \\
\text { CDT } 8\end{array}$ & $\begin{array}{l}\text { In UACDT total t-PA dose } \\
\text { 20mg; In CDT total t-PA dose } \\
23.7 \mathrm{mg}\end{array}$ & $\mathrm{N} / \mathrm{A}$ & $\begin{array}{l}\text { PAP, RVSF, Clot } \\
\text { clearance }\end{array}$ \\
\hline $\begin{array}{l}\text { Lin, et all. } \\
2009 \text { [24] }\end{array}$ & Retrospective & 25 & $25 / 0$ & $\begin{array}{l}\text { UACDT } 11, \\
\text { CDT } 14\end{array}$ & $\begin{array}{l}\text { In UACDT mean total t-PA } \\
\text { dose of } 17.2 \pm 2.36 \mathrm{mg} \text { (range } \\
8-28 \mathrm{mg} \text { ) In CDT mean total } \\
\text { t-PA dose of } 25.43 \pm 5.27 \mathrm{mg} \\
\text { (range } 16-45 \mathrm{mg} \text { ) }\end{array}$ & N/A & $\begin{array}{l}\text { Thrombus clearance } \\
\text { (complete, partial), } \\
\text { Miler score }\end{array}$ \\
\hline $\begin{array}{l}\text { Chamsudiin, } \\
\text { et al. } 2008 \\
\text { [25] }\end{array}$ & $\begin{array}{l}\text { Retrospective } \\
\text { case series }\end{array}$ & 10 & $10 / 0$ & UACDT 10 & $\begin{array}{l}\text { Mean dose of t-PA } 0.88 \mathrm{mg} / \mathrm{h} \\
+/-0.19\end{array}$ & N/A & $\begin{array}{l}\text { Thrombus clearance } \\
\text { (complete, near } \\
\text { complete, partial) }\end{array}$ \\
\hline
\end{tabular}




\section{Cureus}

Quintana, et al. 2013 [26]

Retrospective 10

Fuller, et al.

2017 [28]

Retrospective 27

$0 / 27$

27

McCabe, et

al. 2015 [30]

Retrospective 53

$0 / 53$

Ozmen, et

al. 2015 [31]

Retrospective 10

$0 / 10$

$12 / 33$

al. 2015 [32]

Retrospective 45

Sag, et al.

2016 [33]

Prospective

uncontrolled

13

$13 / 0$

UACDT 13

Total t-PA dose

$30.5 \mathrm{mg}$ (range, 14-66mg)

N/A

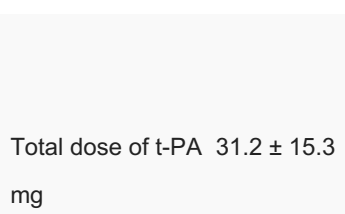

$1.21 \pm 0.19$

vs

$1.01 \pm 0.14$

1.26

(0.76-1.84)

vs 0.91

(0.62-1.10)

pron

pressure

TRV, TAPSE,

pulmonary

acceleration time,

PAP, Qandali score,

RV dysfunction, clot

burden

Hypotension,

tachycardia, cardiac

dysfunction, PAP

RA diameter, RV

diameter RA/LA ratio,

TAPSE, PAP(systolic,

diastolic, mean)

Cardiac output, RA

Prospective

and 45 (15

Bagla, et al.

retrospective

prospective,

30

$0 / 45$

uncontrolled

retrospective)

UACDT 45

$1.59 \pm 0.54$

vs PAP

$0.93 \pm 0.17$

study

(and

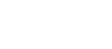

Kaymaz, et

al. 2017 [38]

Retrospective 75

$15 / 60$

UACDT 75

Total t-PA dose $35.4+16.7$

$1.38 \pm 0.26$

vs

$1.17 \pm 0.19$

UCADT 36

CDT 27

In UACDT total t-PA dose $27.5 \quad 1.13 \pm 0.19$

$+12.9 \mathrm{mg}$; In CDT total t-PA vs

dose $23.2+13.7 \mathrm{mg}$;

$0.77 \pm 0.19$

PAP(mean, systolic, diastolic), TAPSE,

RA/LA ratio, Qandali

score, TAPSE, ST,

PA diameter(main,

right, left)

TAPSE, PAP

(systolic), RV dilation,

RV systolic function

$0.9(0.71 .1)$

UACDT Total t-PA dose $21 \mathrm{mg}$

Vs
$0.7(00.97)$

PAP, BNP

UACDT 36,

Kuo, et al. Prospective

CDT 64, CD 


\section{Cureus}

$2015[41]$

\section{TABLE 1: Table representing the summary of studies published for efficacy of ultrasound assisted catheter directed thrombolysis}

UACDT = Ultrasound assisted catheter directed thrombolysis, CDT = Catheter directed thrombolysis, PAP= Pulmonary artery pressure, $\mathrm{PAMP}=$ Mean pulmonary artery pressure RVSF= Right ventricular systolic function, $\mathrm{tPA}=$ Tissue plasminogen activator, $\mathrm{RV}=\mathrm{Right}$ ventricular, $\mathrm{RA}=$ right atrium, LA= Left atrium, UFH= Unfractionated Heparin, GUSTO = Global Utilization of Streptokinase and Tissue Plasminogen Activator for Occluded Coronary Arteries, $\mathrm{CD}=$ Catheter directed, $\mathrm{Cl}=$ Cardiac index, $\mathrm{TRV}=$ Tricuspid regurgitation jet velocity, TAPSE= Tricuspid annular plane systolic excursion, ST= systolic myocardial velocity on tissue Doppler

\section{Safety of ultrasound assisted catheter-directed thrombolysis}

The majority of literature and studies related to UACDT safety is assessed by five major variables including in-hospital mortality, 30 days mortality, 90 days mortality, major bleeding and minor bleeding. Engelhardt, et al. in retrospective study observed no mortality in patients with PE, and all patients were discharged alive [22]. There was not even a single major systemic bleeding complication. However, there were four access site major bleeding complications requiring transfusion and one suspected massive PE recurrence. Similarly, in another study, there were $57 / 60$ patients survived to discharge (one patient died due to intra-abdominal hemorrhage and hypovolemic shock, one patient died due to family opted for comfort care measures and one died due to massive PE) [11]. There was one 90 days mortality during infusion of rt-PA, one patient had an acute renal injury and cardiopulmonary arrest, and one major and minor bleeding episode. This evidence made a consistent result with ULTIMA trial for the safety of UACDT procedure for PE. In ULTIMA trial, there was no death reported but there were three minor bleeding episodes (two with transient hemoptysis without intervention and one with access site hematoma managed with manual compression) in patients with intervention group and one minor bleeding episode (muscular hematoma at injection site of UFH) in patient with control group, and there was no reported episode of recurrent PE seen in either group. Further Engelberger, et al. reported two death during three-month follow-up (one from cardiogenic shock and one from recurrent PE) and two major bleeding episode (one intrathoracic bleeding after cardiopulmonary resuscitation requiring transfusion, one intrapulmonary bleeding requiring lobectomy), but there was no in-hospital mortality reported [18]. Moreover, in SEATTLE II trial total seven mortality (three in-hospital and rest 30-day mortality), 15 major bleeding events within 30 days (14 moderate and one severe bleeding), and five serious adverse events (device related and two rt-PA related) were described [13]. It is because of this consistent safety result the US FDA approved the use of UACDT in the patient with PE. Further in Pulmonary Embolism Response to Fragmentation, Embolectomy, and Catheter Thrombolysis (PERFECT) registry UACDT appears to be safe and effective without any major systemic bleeding including intracranial hemorrhage [41]. There was no intracranial hemorrhage reported with the use of UACDT until recently published case report [42]. But this patient was elderly male of 86 years along with thrombocytopenia on the day patient developed intracranial hemorrhage. It is uncertain whether this bleeding was solely due to use UACDT or multifactorial, considering old age and thrombocytopenia along with rt-PA during the procedure [42].

There was one intracranial hemorrhage reported by Ozcinar, et al. in the prospective observational study [40]. The author could not find any other study of UACDT who had an Intracranial hemorrhage. Overall there is lesser major bleeding event and mortality event with more benefit which suggests better safety of UACDT (Table 2). 


\begin{tabular}{|c|c|c|c|c|c|c|}
\hline Authors & $\begin{array}{l}\text { In- } \\
\text { hospital } \\
\text { mortality }\end{array}$ & $\begin{array}{l}30 \text { days } \\
\text { mortality }\end{array}$ & $\begin{array}{l}90 \text { days } \\
\text { mortality }\end{array}$ & $\begin{array}{l}\text { Major systemic } \\
\text { bleeding episodes in } \\
\text { UACDT }\end{array}$ & $\begin{array}{l}\text { Other bleeding } \\
\text { episodes in } \\
\text { UACDT }\end{array}$ & $\begin{array}{l}\text { PE recurrence in } \\
\text { UACDT during } \\
\text { follow up }\end{array}$ \\
\hline $\begin{array}{l}\text { Dumantepe, et al. } \\
2014 \text { [10] }\end{array}$ & 1 & 0 & 0 & 0 & 2 & 1 \\
\hline $\begin{array}{l}\text { Kennedy, et al. } \\
2013\end{array}$ & 3 & 0 & $4^{*}$ & 1 & 1 & 0 \\
\hline $\begin{array}{l}\text { Kucher, et al. } \\
2013 \text { [12] }\end{array}$ & 0 & 0 & 1 & 0 & 3 & 0 \\
\hline $\begin{array}{l}\text { Piazza, et al. } \\
2014 \text { [13] }\end{array}$ & 3 & 4 & $\mathrm{~N} / \mathrm{A}$ & 12 & 3 & $\mathrm{~N} / \mathrm{A}$ \\
\hline $\begin{array}{l}\text { Engelberger, et } \\
\text { al. } 2013 \text { [18] }\end{array}$ & 0 & 0 & 2 & 2 & 11 & 1 \\
\hline $\begin{array}{l}\text { Engelhardt, et al. } \\
2011 \text { [22] }\end{array}$ & 0 & 0 & 0 & 0 & 6 & 1 \\
\hline $\begin{array}{l}\text { Al-Hakim, et al. } \\
2014 \text { [23] }\end{array}$ & 0 & N/A & $N / A$ & 0 & 1 & $N / A$ \\
\hline $\begin{array}{l}\text { Lin, et all. } 2009 \\
\text { [24] }\end{array}$ & 1 & N/A & $N / A$ & 0 & 0 & $N / A$ \\
\hline $\begin{array}{l}\text { Chamsudiin, et } \\
\text { al. } 2008 \text { [25] }\end{array}$ & 0 & 0 & 0 & 0 & 2 & $\mathrm{~N} / \mathrm{A}$ \\
\hline $\begin{array}{l}\text { Quintana, et al. } \\
2013 \\
{[26]}\end{array}$ & 0 & 0 & 0 & 0 & 2 & 1 \\
\hline $\begin{array}{l}\text { Fuller, et al. } 2017 \\
\text { [28] }\end{array}$ & 0 & N/A & $\mathrm{N} / \mathrm{A}$ & 0 & 4 & $\mathrm{~N} / \mathrm{A}$ \\
\hline $\begin{array}{l}\text { McCabe, et al. } \\
2015 \text { [30] }\end{array}$ & 0 & N/A & N/A & 2 & 3 & N/A \\
\hline $\begin{array}{l}\text { Ozmen, et al. } \\
2015 \text { [31] }\end{array}$ & 1 & 0 & 0 & 0 & 0 & 0 \\
\hline $\begin{array}{l}\text { Nykamp, et al } \\
2015 \text { [32] }\end{array}$ & 0 & 0 & 0 & 0 & 0 & 0 \\
\hline $\begin{array}{l}\text { Sag, et al. } 2016 \\
\text { [33] }\end{array}$ & 1 & 0 & 0 & 0 & 0 & 0 \\
\hline $\begin{array}{l}\text { Bagla, et al. } 2015 \\
\text { [37] }\end{array}$ & 0 & 0 & N/A & 2 & 4 & 0 \\
\hline $\begin{array}{l}\text { Kaymaz, et al. } \\
2017 \text { [38] }\end{array}$ & 4 & $\mathrm{~N} / \mathrm{A}$ & $\mathrm{N} / \mathrm{A}$ & 2 & 5 & 0 \\
\hline
\end{tabular}




\section{Cureus}

Liang, et al. 2016

[39]

Ozcinar, et al.

2017 [40]

0

N/A

N/A

2

2

0

Kuo, et al. 2015

[41]

6

0

0

0

13

N/A

\section{TABLE 2: Table representing the summary of studies published for safety of ultrasound assisted catheter directed thrombolysis}

$\mathrm{N} / \mathrm{A}=$ Not available, $\mathrm{PE}=$ Pulmonary embolism

*4= 3 in-hospital and 1 after discharge within 90 days.

\section{Complications}

There are numbers of complications related to UACDT, Including vascular access related complications (bleeding, hematoma, rupture of vessels), cardiogenic shock, pulmonary hemorrhage, perforation or dissection of the pulmonary artery, and pericardial tamponade [43]. Other more common complications are arrhythmias and right sided valvular regurgitation [43]. Moreover, the use of contrast also leads to contrast-induced nephropathy [43]. Finally, the cost of the procedure compared to systemic thrombolysis as UACDT is more expensive than systemic thrombolysis [43]. Moreover Liang, et al. stated that there are no statistical differences in clinical, hemodynamic outcomes and procedural complication rates between UACDT and standard catheter-directed thrombolysis without ultrasound [39]. However this study had several important limitations including relatively smaller sample size, changing procedural protocol, and absence of post-procedure testing to demonstrate any improvement.

\section{Limitations}

It is unclear whether UACDT acts fast enough to prevent hemodynamic compromise and death in unstable patients. Other limitations are long duration procedure (15-24 hours), expensive procedure, limited availability in majority hospitals, unsure about the recurrence of PE, and chances of chronic thromboembolic PAH.

\section{Conclusions}

Ultrasound-assisted catheter-directed thrombolysis (UACDT) is emerging and alternative revascularization procedure to systemic thrombolysis and surgical embolectomy for PE. UACDT is superior in improving $\mathrm{RV} / \mathrm{LV}$ ratio, PAP, thrombotic burden and cardiac index with a lower risk of bleeding and other complications. UACDT procedure is performed in the limited hospital with around the clock availability of catheter therapy and surgical embolectomy. There is no head to head prospective randomized trial to compare UACDT with catheter-directed thrombolysis without ultrasound and UACDT with systemic thrombolysis. Further prospective randomized studies are warranted to compare the efficacy and safety of UACDT with catheterdirected thrombolysis without ultrasound and systemic thrombolysis.

\section{Additional Information}

\section{Disclosures}


Conflicts of interest: In compliance with the ICMJE uniform disclosure form, all authors declare the following: Payment/services info: All authors have declared that no financial support was received from any organization for the submitted work. Financial relationships: All authors have declared that they have no financial relationships at present or within the previous three years with any organizations that might have an interest in the submitted work. Other relationships: All authors have declared that there are no other relationships or activities that could appear to have influenced the submitted work.

\section{References}

1. Avgerinos ED, Chaer RA: Catheter-directed interventions for acute pulmonary embolism. J Vasc Surg. 2015, 61:559-565. 10.1016/j.jvs.2014.10.036

2. Goldhaber SZ, Visani L, De Rosa M: Acute pulmonary embolism: clinical outcomes in the International Cooperative Pulmonary Embolism Registry (ICOPER). Lancet. 1999, 353:13861389. 10.1016/S0140-6736(98)07534-5

3. Wood KE: Major pulmonary embolism: Review of a pathophysiologic approach to the golden hour of hemodynamically significant pulmonary embolism. Chest. 2002, 121:877-905. 10.1378/chest.121.3.877

4. Kline JA, Steuerwald MT, Marchick MR, et al.: Prospective evaluation of right ventricular function and functional status 6 months after acute submassive pulmonary embolism: frequency of persistent or subsequent elevation in estimated pulmonary artery pressure. Chest. 2009, 136:1202-1210. 10.1378/chest.08-2988

5. Klok FA, Zondag W, van Kralingen KW, et al.: Patient outcomes after acute pulmonary embolism. A pooled survival analysis of different adverse events. Am J Respir Crit Care Med. 2010, 181:501-506. 10.1164/rccm.200907-11410C

6. Schoepf UJ, Kucher N, Kipfmueller F, et al.: Right ventricular enlargement on chest computed tomography: a predictor of early death in acute pulmonary embolism. Circulation. 2004, 110:3276-3280. 10.1161/01.CIR.0000147612.59751.4C

7. van der Meer RW, Pattynama PM, van Strijen MJ, et al.: Right ventricular dysfunction and pulmonary obstruction index at helical CT: prediction of clinical outcome during 3-month follow-up in patients with acute pulmonary embolism. Radiology. 2005, 235:798-803. 10.1148/radiol.2353040593

8. Fiumara K, Kucher N, Fanikos J, et al.: Predictors of major hemorrhage following fibrinolysis for acute pulmonary embolism. Am J Cardiol. 2006, 97:127-129. 10.1016/j.amjcard.2005.07.117

9. Kilic A, Shah AS, Conte JV, et al.: Nationwide outcomes of surgical embolectomy for acute pulmonary embolism. J Thorac Cardiovasc Surg. 2013, 145:373-377. 10.1016/j.jtcvs.2012.01.066

10. Dumantepe M, Uyar I, Teymen B, et al.: Improvements in pulmonary artery pressure and right ventricular function after ultrasound-accelerated catheter-directed thrombolysis for the treatment of pulmonary embolism. J Card Surg. 2014, 29:455-463. 10.1111/jocs.12354

11. Kennedy RJ, Kenney HH, Dunfee BL: Thrombus resolution and hemodynamic recovery using ultrasound-accelerated thrombolysis in acute pulmonary embolism. J Vasc Interv Radiol. 2013, 24:841-848. 10.1016/j.jvir.2013.02.023

12. Kucher N, Boekstegers P, Müller OJ, et al.: Randomized, controlled trial of ultrasound-assisted catheter-directed thrombolysis for acute intermediate-risk pulmonary embolism. Circulation. 2014, 129:479-486. 10.1161/CIRCULATIONAHA.113.005544

13. Piazza G, Hohlfelder B, Jaff MR, et al.: A prospective, single-arm, multicenter trial of ultrasound-facilitated, catheter-directed, low-dose fibrinolysis for acute massive and submassive pulmonary embolism: The SEATTLE II study. JACC Cardiovasc Interv. 2015, 8:1382-1392. 10.1016/j.jcin.2015.04.020

14. FDA News Simplifying Global Compliance; FDAnews Device Daily Bulletin Medical Devices / Submissions and Approvals; FDA Clears EKOS EkoSonic Endovascular System. (2014). Accessed: 01/2017: http://www.fdanews.com/articles/164759-fda-clears-ekos-ekosonicendovascular-system.

15. Furlan A, Aghayev A, Chang HCC, et al.: Short-term mortality in acute pulmonary embolism: Clot burden and signs of right heart dysfunction at CT pulmonary angiography. Radiology. 
2012, 265:283-293. 10.1148/radiol.12110802

16. Sanchez O, Trinquart L, Caille V, et al.: Prognostic factors for pulmonary embolism: the prep study, a prospective multicenter cohort study. Am J Respir Crit Care Med. 2010, 181:168-173. 10.1164/rccm.200906-09700C

17. Kabrhel C, Okechukwu I, Hariharan P, et al.: Factors associated with clinical deterioration shortly after PE. Thorax. 2014, 69:835-842. 10.1136/thoraxjnl-2013-204762

18. Engelberger RP, Moschovitis A, Fahrni J, et al.: Fixed low-dose ultrasound-assisted catheterdirected thrombolysis for intermediate and high-risk pulmonary embolism. Eur Heart J. 2015, 36:597-604. 10.1093/eurheartj/eht531

19. Francis CW, Blinc A, Lee S, et al.: Ultrasound accelerates transport of recombinant tissue plasminogen activator into clots. Ultrasound Med Biol. 1995, 21:419-424. 10.1016/03015629(94)00119-X

20. Braaten JV, Goss RA, Francis CW: Ultrasound reversibly disaggregates fibrin fibers. Thromb Haemost. 1997, 78:1063-1068.

21. Siddiqi F, Odrljin TM, Fay PJ, et al.: Binding of tissue-plasminogen activator to fibrin: Effect of ultrasound. Blood. 1998, 91:2019-2025.

22. Engelhardt TC, Taylor AJ, Simprini LA, et al.: Catheter-directed ultrasound-accelerated thrombolysis for the treatment of acute pulmonary embolism. Thromb Res. 2011, 128:149154. 10.1016/j.thromres.2011.05.014

23. Al-Hakim R, Genshaft S, Mc William J, et al.: Catheter-directed thrombolysis for the management of submassive pulmonary embolism: single institutional experience over 6 years. ESTI. 2014, 29:39. 10.13140/2.1.1545.4404

24. Lin PH, Annambhotla S, Bechara CF, Athamneh H, et al.: Comparison of percutaneous ultrasound-accelerated thrombolysis versus catheter-directed thrombolysis in patients with acute massive pulmonary embolism. Vascular. 2009, 17:137-147.

25. Chamsuddin A, Nazzal L, Kang B, et al.: Catheter-directed thrombolysis with the Endowave system in the treatment of acute massive pulmonary embolism: A retrospective multicenter case series. J Vasc Interv Radiol. 2008, 19:372-376. 10.1016/j.jvir.2007.10.019

26. Quintana D, Salsamendi J, Fourzali R, et al.: Ultrasound-assisted thrombolysis in submassive and massive pulmonary embolism: Assessment of lung obstruction before and after catheterdirected therapy. Cardiovasc Intervent Radiol. 2014, 37:420-426. 10.1007/s00270-013-0696-X

27. Frémont B, Pacouret G, Jacobi D, et al.: Prognostic value of echocardiographic right/left ventricular end-diastolic diameter ratio in patients with acute pulmonary embolism: results from a monocenter registry of 1,416 patients. Chest. 2008, 133:358-362. 10.1378/chest.071231

28. Fuller TJ, Paprzycki CM, Zubair MH, et al.: Initial experiences with endovascular management of submassive pulmonary embolism: Is it safe?. Ann Vasc Surg. 2017, 38:158-163 . 10.1016/j.avsg.2016.09.002

29. Becattini C, Agnelli G, Salvi A, et al.: Bolus tenecteplase for right ventricle dysfunction in hemodynamically stable patients with pulmonary embolism. Thromb Res. 2010, 125:82-86. 10.1016/j.thromres.2009.09.017

30. McCabe JM, Huang PH, Riedl L, et al.: Usefulness and safety of ultrasound-assisted catheterdirected thrombolysis for submassive pulmonary emboli. Am J Cardiol. 2015, 115:821-824. 10.1016/j.amjcard.2014.12.050

31. Ozmen C, Deniz A, Akilli RE, et al.: Ultrasound-accelerated thrombolysis may be an effective and safe treatment modality for intermediate risk/submassive pulmonary embolism. Int Heart J. 2016, 57:91-95. 10.1536/ihj.15-271

32. Nykamp M, VandenHull A, Remund T,et al.: Safety and efficacy of ultrasound-accelerated catheter-directed lytic therapy in acute pulmonary embolism with and without hemodynamic instability. Vasc Surg Venous Lymphat Disord. 2015, 3:251-257. 10.1016/j.jvsv.2015.03.001

33. Sag S, Nas OF, Kaderli AA, et al.: Catheter-directed ultrasound-accelerated thrombolysis may be life-saving in patients with massive pulmonary embolism after failed systemic thrombolysis. J Thromb Thrombolysis. 2016, 42:322-328. 10.1007/s11239-016-1370-3

34. Ribeiro A, Lindmarker P, Johnsson H, et al.: Pulmonary embolism: One-year follow-up with echocardiography doppler and five-year survival analysis. Circulation. 1999, 99:1325-1330. 10.1161/01.CIR.99.10.1325

35. Fasullo S, Scalzo S, Maringhini G, et al.: Six-month echocardiographic study in patients with submassive pulmonary embolism and right ventricle dysfunction: comparison of thrombolysis 
with heparin. Am J Med Sci. 2011, 341:33-39. 10.1097/MAJ.0b013e3181f1fc3e

36. Sharma GV, Folland ED, McIntyre KM, et al.: Long-term benefit of thrombolytic therapy in patients with pulmonary embolism. Vasc Med. 2000, 5:91-95. 10.1177/1358836X0000500205

37. Bagla S, Smirniotopoulos JB, van Breda A, et al.: Ultrasound-accelerated catheter-directed thrombolysis for acute submassive pulmonary embolism. J Vasc Interv Radiol. 2015, 26:10011006. 10.1016/j.jvir.2014.12.017

38. Kaymaz C, Öztürk S, Akbal Ö, et al.: Ultrasound-assisted catheter-directed thrombolysis in high-risk and intermediate-high-risk pulmonary embolism: Results from a single-center cohort. Angiology. 2017, 68:433-440. 10.1177/0003319716661446

39. Liang NL, Avgerinos ED, Marone LK, et al.: Comparative outcomes of ultrasound-assisted thrombolysis and standard catheter-directed thrombolysis in the treatment of acute pulmonary embolism. Vasc Endovascular Surg. 2016, 50:405-410. 10.1177/1538574416666228

40. Ozcinar E, Cakici M, Yaman DN, et al.: Thrombus resolution and right ventricular functional recovery using ultrasound-accelerated thrombolysis in acute massive and submassive pulmonary embolism. Int Angiol. 2017, 10.23736/S0392-9590.17.03775-0

41. Kuo WT, Banerjee A, Kim PS, et al.: Pulmonary Embolism Response to Fragmentation, Embolectomy, and Catheter Thrombolysis (PERFECT): Initial results from a prospective multicenter registry. Chest. 2015, 148:667-673. 10.1378/chest.15-0119

42. Ganatra S, Majithia A, Yeh YE, et al. : Intracranial hemorrhage in a patient with sub-massive pulmonary embolism treated with EkoSonic endovascular system directed thrombolysis. Catheter Cardiovasc Interv. 2017, 10.1002/ccd.27045

43. Mostafa A, Briasoulis A, Telila T, et al.: Treatment of massive or submassive acute pulmonary embolism with catheter-directed thrombolysis. Am J Cardiol. 2015, 117:1014-1020.

10.1016/j.amjcard.2015.12.041 